\title{
SINCRETISMO DE GÊNERO O PERSONAGEM ISABEL, DE LOS RECUERDOS DEL PORVENIR
}

Mercedes Cavalcanti (UFPB)

Resumo: Na obra Los recuerdos del porvenir ${ }^{1}$, da escritora mexicana Elena Garro, a personagem Isabel sintetiza os desafios da condição do gênero feminino: por um lado, herdou a cultura ancestral das mulheres que a precederam, personificando uma identidade genérica como um sujeito histórico centrado em "ser para os outros" - nesse sentido, incorpora a mulher pré-moderna ou tradicional. Por outro lado, revela uma vontade própria que a leva ao desdobramento na busca de sua identidade individual "ser para si", assumindo-se como uma mulher transgressora em relação aos códigos preestabelecidos. Por esse prisma, integra os elementos que exprimem uma atitude mais representativa da mulher moderna. Concomitantemente plasmadas e em conflito, estas fórmulas inerentes ao personagem Ihe imprimem uma complexidade e verticalidade, em que coexistem duas incompreendidas e solitárias isabéis.

Palavras-chave: Literatura mexicana; Escritora mulher; Elena Garro; Personagem feminino, Questão de gênero.

Resumen: En el libro "Los recuerdos del porvenir", la escritora mexicana Elena Garro construye Isabel, caracter que personifica los desafíos de la condición femenina: por un lado, heredada de la cultura ancestral de las mujeres que la precedieron, suplantando una identidad genérica centrada en el sujeto histórico "ser para los otros" en ese sentido, y así incorpora la mujer premoderna o tradicional. De otra parte, revela una voluntad que conduce a nuevos avances en la búsqueda de su identidad individual "ser para sí", asumiéndose como una mujer transgresora en relación a los códigos predeterminados. Desde esta perspectiva, integra los elementos que expresan una actitud más representativa de la mujer moderna. Concomitantemente moldeado y en conflicto, estas fórmulas inherentes al carácter que imprime una complejidad y la verticalidad, en la que hay dos solitaria incompreendidas e Isabéis.

1 Atualmente, Los recuerdos del porvenir se acha em processo tradutório pela autora deste ensaio, sob o título provisório de Lembranças do Amanhã. 
Palabras-clave: La literatura mexicana; Escritora; Elena Garro; Personaje femenino; Cuestión de género.

Aqui, a ilusão se paga com a vida². Elena Garro

Ao longo da história, a literatura tem ostentado escritoras que, mesmo que não o tenham intencionalmente definido como objeto de sua escritura, oferecem ao gênero feminino uma via de reflexão sobre a busca da liberdade. Seja com seu exemplo e testemunho, seja através da escritura, dos temas escolhidos, personagens, etc., essas autoras, de uma forma ou de outra, têm oferecido uma contribuição para o movimento pelos direitos das mulheres.

Paradigma perfeito e quase unânime é a mexicana Sor Juana Inés de la Cruz. Nas primícias da civilização hispânica de seu país, destacou-se, embora sendo mulher, bastarda e freira. Vivendo em uma sociedade patriarcal, no período da Inquisição, foi, por sua atitude como ser humano e pela sua escritura como poeta, filósofa e ensaísta, um exemplo de coragem e denodo inusual no discurso literário especialmente feminino - daquela época. Por sua inteligência crítica e interpretação da condição feminina avançada para a época, Juana Inés constitui uma das representações mais enaltecidas das ideologias feministas de todos os tempos.

2 Tradução livre do original em espanhol: "Aquí la ilusión se paga con la vida". 
Obviamente, frente às contingências atuais, tais movimentos não mais possuem o radicalismo do passado. Eles se adaptaram a um cenário que, se não mudou muito em uma perspectiva vertical, sem dúvida foi ajustado em vários níveis. A verdade é que ainda persistem, de forma evidente ou escamoteada, as idiossincrasias de especificidade do mundo feminino. Estão difundidas em todas as áreas familiares, educacionais, profissionais, entre outras.

A própria religião não se encontra isenta de ambiguidades e/ou preconceitos no que diz respeito às mulheres. Ao contrário, frequentemente, alguns de seus representantes demonstram um beneplácito magnânimo com relação a uma alegada má conduta do homem, enquanto que, pela mesma ação, costumam condenar a mulher.

Explana Marcela Lagarde que "na visão androcêntricado mundo, que prevalece nessa região, as mulheres não conseguem o seu espaço como outro sujeito histórico"33 (1990, p.26). De fato, historicamente, o gênero feminino tem sido negligenciado e escanteado, como resultado da mentalidade androcêntrica, que induz a um entendimento mecanicista e falacioso, segundo o qual o homem seria o único ser atuante da história.

3 Tradução do original: "En La visión androcéntrica del mundo, que prevalece en esta región, las mujeres no tienen cabida como otro sujeto histórico". 
Trata-se de uma aberração interpretativa, que deveria ser sepultada para sempre. É imprescindível acabar com a concepção equivocada de uma suposta passividade feminina. Urge assegurar que prevaleça uma atitude dialética e dialógica, que resgate a verdadeira função e importância da mulher como elemento dinâmico na história.

O gênero feminino deve ser focalizado e interpretado sem discriminação e suas peculiaridades, consideradas. Sem dúvida, haverá ocasiões em que se perpetrarão imbricações, porém em muitas outras ocorrerão diferentes ramificações, em diversos níveis da natureza interior e exterior dessas duas expressões genéricas do ser humano.

Deste modo, é necessário reiterar-se que, ao pretenderse realizar um estudo coerente da condição feminina, seja no contexto da realidade, seja do imaginário, deve-se levar em conta o conceito de gênero. Com efeito, "para estudar a literatura escrita por mulheres, é insuficiente empregar as ferramentas tradicionais de crítica literária" dogmatiza Aralia López González (1995, p. 11)

Seguindo o mesmo raciocínio, tampouco se pode estudar as personagens femininas sem utilizar os instrumentos adequados para esse fim. É que o ser humano masculino

4 Tradução livre do original: "al estudiar la literatura escrita por mujeres, resulta insuficiente acercarse a ella com las herramientas tradicionales de la crítica literaria". 
e o ser humano feminino transitam em dimensões de múltiplas realidades que às vezes mal se tocam no espaço das atitudes, papéis, funções e comportamentos que a sociedade espera de cada um.

Fazem parte dessas expectativas a percepção, o discernimento e a interpretação do significado de identidade e liberdade, no que concerne às atitudes de especificidade dele ou dela. Tanto no nível de subjetividade, como das práticas sociais, os conceitos de identidade e liberdade assumem diferentes facetas. Estas se encontram arraigadas, quiçá não tanto no âmbito do consciente, mas, sobretudo, no do inconsciente e das formas de expressão do comportamento.

Em virtude de tão significativas "diferenças", o investigador da área literária ficcional se arriscará a cometer lapsos e deslizes importantes se ignorar essas reflexões, de modo que, ao examinar-se uma personagem feminina, torna-se substancial considerar a "diferença" genérica. Caso contrário, torna-se impossível realizar uma avaliação clara, com a necessária profundidade.

No século XX, surge em Puebla, no México, uma expressão viva do que se afirma supra. Trata-se da "grande escritora, jornalista e dramaturga mexicana Elena Garro (1920 ou 1922-1998), escorraçada pelos intelectuais liderados por 
seu próprio marido, o célebre Octavio Paz, sob cuja sombra passou quase ao esquecimento" (CAVALCANTI, 2011, p.10). De fato, a mencionada autora é uma das literatas mais notáveis por revelar e sublinhar as idiossincrasias do gênero feminino. Constitui um grande exemplo disso Los recuerdos del Porvenir (2010) sua obra-prima, de cujo texto se infere sua luta interior entre o "ser" e "dever ser".

Tendo sido sua primeira edição publicada vários anos antes do célebre livro Cem Anos de Solidão (1967), de Gabriel García Márquez, o romance de Garro contém muitos elementos que aparecem mais tarde no do escritor colombiano, seja por influência direta, seja por um fenômeno do inconsciente coletivo. Ambos transitam pelo estilo Fantástico. Caminham, os dois, pelas veredas do real e do imaginário.

Igualmente, nas citadas obras, conduz-se o tempo na temporalidade (o porvir, o haver sido, e o estar aqui e agora) de Heidegger (2009) que permite aos personagens, situados em um suposto presente, evocarem o futuro e vislumbrarem o seu fracasso. Além disso, uma e outra são obras intrigantes de densidade e complexidade indizíveis, catalisando reflexões nos mais variados níveis.

5 Embora se coteje aqui a edição de 2010, no ano de 1953, Elena Garro já havia escrito a obra mencionada, que ficou esquecida, literalmente, em um baú, até 1963, data de sua publicação. 
Entretanto, enquanto a García Márquez foi concedida a benesse de apreciar o sucesso e ganhar o Prêmio Nobel de Literatura, Garro envolveu-se em infaustos eventos de ordem político-social. Em primeiro lugar, era visceralmente odiada tanto pela classe política como pela classe intelectual. Afrontava-os ao exigir-lhes que, em vez de discussões abstratas, partissem para a praxis, solucionando, efetivamente, as injustiças vigentes em relação à situação dos índios e à condição da mulher.

O divisor de águas, o verdadeiro cataclismo que transformou os rumos de sua vida pessoal e literária foi a sua atuação no movimento estudantil de 1968. Nesse episódio, quando foram assassinados mais de duzentos jovens pelas hostes governamentais, a escritora desempenhou um papel extremamente controverso. Segundo ela, embora inicialmente houvesse apoiado o movimento, logo se posicionou contra, ao perceber políticas dúbias e também ao pressentir o massacre que se abateria sobre os estudantes.

Após o terrível episódio, a imprensa publicou uma delação na forma de uma lista de intelectuais supostamente envolvidos no massacre. A matéria teria sido assinada e enviada aos jornais pela escritora. Todavia, ela passou o resto de sua vida refutando as acusações referentes à autoria 
desse documento. Assim é que, na hipótese de ela ter falado a verdade, presume-se que tenha sido vitima de um complô para livrar-se de uma ativista extremamente incômoda ao poder estabelecido e aos intelectuais que ela acusava de indiferentes aos problemas sociais.

Independentemente de haver sido ou não o bode expiatório da revolta estudantil, o fato é que o massacre e seus desdobramentos fizeram com que rompesse, definitivamente, suas relações com o ex-marido Octavio Paz, que passou a atacá-la implacavelmente, apoiado pelos intelectuais da época, nos quais exercia uma forte e indisfarçável liderança. De tal modo a perseguiram, que foi forçada a se exilar na Espanha e, finalmente, na França, onde levou uma existência difícil e quase anônima.

Somente voltaria ao México em 1993, depois de vinte anos e um poço de infortúnios. Desamparada, mudou-se para Cuernavaca, em um pequenino apartamento emprestado. Idosa e enferma, encontrava-se em uma condição quase indigente, ainda rejeitada por uma parcela da imprensa e por um grande segmento de intelectuais. Até mesmo os cuidados médicos e os medicamentos eram doados. Deste modo, Los Recuerdos del Porvenir permaneceu um longo tempo esquecido - um destino inversamente proporcional 
à obra Cem Anos de Solidão, romance que pode ter sido baseado no de Garro.

Na obra da escritora observa-se que a construção das personagens do gênero feminino é particularmente elaborada, detalhada, enriquecida de milhares de ingredientes, tanto em relação ao nível psicológico, como ao nível de sua atitude comportamental no seio de sua comunidade. A verdade é que poucos escritores foram tão iluminados e profundos na concepção da alma feminina como Elena Garro. Com uma redação impecável e criativa, ela descreve como ninguém o espírito ardente e inquieto aprisionado no corpo aparentemente frágil de uma mulher, a qual se acha incrustada em uma sociedade que costuma portar-se culturalmente desfavorável a sua condição feminina.

Talvez nenhum personagem da autora mencionada seja tão complexo e significativo como Isabel, do romance Los Recuerdos del Porvenir. Multifacetada, essa figura indócil, de alma insondável eleva à potência máxima o conceito de personagem "redondo". Em que pese o posicionamento de Fabienne Bradu na contra capa de uma das edições do romance (GARRO, 2010), assegura que a pesonagem "Julia resume em sua vida o paradoxo das mulheres Elena 
Garro"6, a verdade é que, embora a princípio a narradora não o evidencie, (obviamente para salvaguardar a revelação final do texto, levando o leitor à catarse) é Isabel quem realmente desempenha essa função. Se Bradu defende a sua tese acrescentando que Julia "é uma vítima, prisioneira de um homem poderoso e, ao mesmo tempo, detentora de um poder que, por ser mágico e misterioso, aniquila todas as formas de poder humano", ainda é Isabel quem, embora sendo uma jovem superprotegida de família tradicional, participa mais intensamente do destino de seu povo, como se depreende no final da narrativa.

Em uma trama na qual os protagonistas parecem se alternar, Isabel personifica o fio condutor da história. É ela que, possuindo uma energia e um desbordamento irreprimível, tem que refreá-los por sua condição de mulher. Interfere em todos os destinos quando decide confrontar a sociedade e os "bons costumes", e se entrega a uma paixão proibida. Paradoxalmente, em vez de obter a felicidade que tanto anseia, contribui a desencadear a tragédia para si e toda a sua família, pois à mulher não é permitido desfrutar o fogo da paixão, a não ser através de canais religiosos e burocráticos. Caso contrário, "viola" as regras, os códigos e

6 Traduzido do fragmento original em espanhol: "Julia resume en su vida la paradoja de las mujeres de Elena Garro". 
as convenções da sociedade e da cultura na qual se insere. Em suma, comete um "pecado" que jamais será perdoado.

Transitando na contramão de outros personagens femininos cujo comportamento é estereotipado, claro, definido e previsível; Isabel, por outro lado, surpreende e assombra. Ousa insurgir-se contra a situação desvantajosa de subordinação do corpo e da alma, do sexo e da mente, de sua sensibilidade e de sua inteligência, e até mesmo da sua imaginação e de seu intelecto. Embora herde as tradições rígidas de seus antepassados, personificando uma identidade genérica como sujeito histórico caracterizado em "ser para os outros", decide se arriscar. Despe-se dos véus que a aprisionam, desvelando uma atitude individual que a conduz ao desdobramento na sua busca de "ser para si", cumprindo a sua vontade de ser-se. Concomitantemente plasmadas e em conflito, as fórmulas inerentes ao personagem lhe imprimem uma complexidade e verticalidade, em que coexistem várias incompreendidas e solitárias Isabéis.

Como se fosse feita de diferentes imagens refletidas de um espelho, Isabel é a narradora e por meio de seu olhar feminino a história é narrada. Personagem dividido entre as imposições sociais e os desejos individuais, esconde uma alma rebelde e vivaz, mas também se apresenta como 
vítima das amarras de sua condição feminina. Experimenta desejos indomáveis e por longo tempo coibidos. Constitui, ela mesma, uma energia vibrante, voraz, cheia de vida. Mas também é a pedra em que se transforma ao ver a sua paixão cerceada pelo status quo, pelas amarras culturais e pela morte de todas as esperanças na dimensão do afeto, da paixão e das aspirações, tanto em nível individual como no coletivo, de sua família e de sua comunidade.

Não se pode esquecer - e, portanto, se torna essencial repisar - que a audácia de Isabel não permanece impune. O fato de dar as costas a toda uma estrutura sedimentada de castrações dirigidas particularmente à mulher acarretaIhe terríveis consequências que a arrastam à sua destruição. Isso, em última análise, não é senão um castigo imputado simultaneamente por um arcaico Deus justiceiro e pela hipocrisia dos seres terrenos.

Contudo, ao enfrentar os riscos e as incertezas, e assumir-se como uma mulher transgressora dos códigos preestabelecidos, a identidade do "ser para si" se superpõe à identidade ensinada e praticada através de inúmeras gerações do "dever ser feminino" ou "ser para outros". O gênero feminino, tal como tem sido moldado por milênios, submerge nas águas de um novo olhar do personagem 
Isabel. Um olhar reflexivo e autorreflexivo, crítico e questionador, no que tange aos costumes impostos pela sociedade patriarcal. Olhos renovados que retiram da face dos espelhos um reflexo diferente, que a individualiza, em contraste com a esperada conduta genérica. Emergindo do gênero plural sedimentado através dos tecidos milenares da cultura, surge um gênero singular construído a partir do prisma oriundo desse novo olhar.

Não se pode perder de vista que esse novo olhar ainda se acha contaminado e meio entrelaçado no olhar antigo. Afinal, a identidade do novo Eu nasce do mesmo útero onde se encontra a identidade de gênero tradicional, que ainda vê a mulher somente através de uma concepção intrinsecamente atada aos deveres de mãe, apenas uma dona de casa anônima criatura do lar.

Por essa razão, Isabel é pressionada pela luta interior deflagrada por suas múltiplas identidades. Deseja albergar sua recém-nascida perspectiva de conceber o mundo segundo o conceito de "ser para si", mas se vê acossada pela compulsão ancestral de "ser para todos". Assim, não consegue impor-se totalmente à sua nova faceta.

Viandante incansável nesse processo de transição, Isabel simboliza essa luta em busca da liberdade de ser ela mesma. 
Procedente de uma família tradicional, dela se espera uma "bem educada" finura, circunspecção e moderação, em que ser mulher significa aparecer o minimamente possível, menos ainda que os móveis que a rodeam. Isto, praticamente, arremete a um estado de invisibilidade.

Entretanto, Isabel se permite render-se à sua energia interior e, de repente, é vista em uma reunião, "dançando com o seu irmão Nicolás, no corredor iluminado por lanternas alaranjadas, rodopiando sobre os seus calcanhares, com os cachos de seus cabelos em desalinho e um sorriso deslumbrado nos lábios (...)" (GARRO, 2010, p. 14). A comunidade inteira recrimina sua espontaneidade como algo inaceitável à sua condição de mulher. $\mathrm{O}$ ademã materno representa o pensamento de sua família, embora não de seu irmão Nicolás: "Sua mãe olha com censura". Preconceituosamente, o pensamento de todos converge para uma conclusão sombria: "Eles vão acabar malsentenciam as pessoas - (...)". E mais adiante gritam: "Isabel, para quem você está dançando? Você parece uma louca!"7 (GARRO, 2010, p. 14).

À frente de seu tempo, a protagonista se asfixia num poço de defasagem cultural entre o passado, presente e futuro. Por

7 Traduzido dos fragmentos originais em espanhol: "bailando com su hermano Nicolás, em el corredor iluminado por las linternas anaranjadas, girando sobre sus tacones, com los rizos em desorden y una sonrisa encandilada em los labios. (...)" / "Su madre la mira con reproche". / "No van a acabar bien - sentencian la gentes (...)" / “¿lsabel, para quién bailas? ¡Pareces una loca!" 
sua vez, essa amálgama de diferentes elementos patenteia e compõe um sincretismo de gênero que se constitui uma das características identitárias da mulher latino-americana moderna. Mulher que, ao mesmo tempo, habita um mundo povoado de sincretismos resultantes do aglutinamento das discrepâncias que nem a passagem dos séculos, nem os movimentos independentistas, conseguiram jamais superar.

Isabel só se reconhece como real, como ela mesma, na medida em que, aos olhos do mundo, deixa precisamente de sê-lo. Para alcançar o Eu, viajar para o "centro" do seu ser, "a caminhada é árdua, está semeada de perigos, porque, na verdade, é um rito de passagem do profano ao sagrado; do efêmero e ilusório à realidade e à eternidade; da morte para a vida; do homem à divindade"8 (ELIADE, 2001, p.15). No entanto, após o sacrifício, advém o prêmio, pois “o acesso ao 'centro' equivale a uma consagração, a uma iniciação; a existência ontem profana e ilusória é agora substituída por uma nova existência real, duradoura e eficaz"9 (ELIADE, 2001, p.15).

É emblemático que, ao se transmutar em pedra, não seja uma pedra qualquer, mas do cemitério - de um "campo

8 Tradução do original em espanhol: "el camino es arduo, está sembrado de peligros, porque, de hecho, es un rito del paso de lo profano a lo sagrado; de lo efímero y lo ilusorio a la realidad y la eternidad; de la muerte a la vida; del hombre a la divinidad".

9 Traduzido do original em espanhol: "el acceso al 'centro' equivale a una consagración, a una iniciación; a una existencia ayer profana e ilusoria, sucede ahora una nueva existencia real, duradera y eficaz". 
santo": ora, para os católicos, a morte contém em seu bojo a ideia de ressurreição. Portanto, apesar de na inscrição colocada na pedra-Isabel, a considerarem morta e liquidada, não se deve concluir que o personagem sucumbe derrotado.

Tampouco devem prevalecer as palavras mordazes escritas na lápide, onde a empequenecem e degradam, acusando-a de haver, por seu pecado de amor, causado a desgraça de sua família, transformando-se em pedra como um castigo consequente do pecado. Obviamente, se fosse interpretado sob esse ângulo unilateral, sem dúvida pareceria que Isabel teria mesmo perdido a batalha que se propôs para defender a sua liberdade e, por extensão, o livre-arbítrio do gênero feminino.

Deste modo, há que se perscrutar o que está por trás do espelho aparente, para evitar a tentação de rotular Los recuerdos del porvenir como um texto pessimista, em que todos - especialmente o personagem de gênero feminino, representado por Isabel - terminassem destruídos. Ao contrário; o fato de que, ao metamorfosear-se, passe a corporificar a sua comunidade e a sua própria cidade é muito sugestivo como argumento e ratificação de que a morte não aponta o fim da linha, mas um renascimento.

Ora, a pedra não é um elemento escolhido aleatoriamente 
por Garro. Em qualquer perspectiva, revela-se significativo que a protagonista de Los Recuerdos del Porvenir tenha se transmutado exatamente em pedra e não em outra substância qualquer. É preciso ligar-se nas especificidades que a tornam especial, influindo na preferência da autora: sabe-se que a pedra é um componente de origem natural caracterizado por uma elevada consistência. Ademais, não parece ser mera coincidência o fato de ser a matéria que melhor se conserva na natureza, ecom a qual se construíram as primeiras ferramentas e se erigiram edifícios e cidades cujas relíquias até hoje permanecem.

Se a metamorfose de Isabel a faz incorporar a cidade, esse fato remete, simbolicamente, à pedra angular, aos primórdios do povo. Após a consumação, tudo se reconstruirá, visto que retorna às suas origens, porque, ao se transmutar em pedra, Isabel "morre", a fim de nascer novamente, como se estivesse submetida ao sortilégio de Zaratustra - aproveitando-se aqui a concepção nietzscheana (NIETZSCHE, 2011). Morrer e ressurgir para sempre, como no mito do eterno retorno tão bem descrito por Mircea Eliade (2001).

Por outras palavras, sob essa concepção, Isabel regressa a sua origem sagrada, de volta à terra mãe, por meio de uma batalha intrínseca e extrínseca, na qual ela, após consumar a paixão proibida e contribuir, embora involuntariamente, 
para a tragédia de sua família, consome-se para se purificar. Com o ritual de ablução, ela se renova, eternamente ressuscitada na simbologia da pedra basilar, que remete à ideia de construção.

É ainda interessante observar que essa representação de circularidade prognosticada pela sequência de nascimento, morte e ressurreição, encontra-se presente em outras obras de Garro. Atesta Carlos Loya (2008, p. 460) que a autora, quando "utiliza seus personagens para ressaltar as figuras simbólicas mais proeminentes nos aspectos sociais e existenciais, destacam fundamentalmente a luta entre a solidão e o desejo de um querer renascer" ${ }^{10}$

Essa restauração será obtida através de uma função que, no passado, era normalmente executada pelo sexo masculino: a da transmissão da memória de seu povo. No relato garriano, o personagem em tela toma para si essa prerrogativa, assumindo o lugar de memória e da palavra e dando voz ao gênero feminino. Uma mulher poderosa, na qual se encaixa o conceito de simultaneamente "ser para si" e "ser para todos"; incorporando o Eu e sua cidade, da qual, no seu novo semblante, constitui pedra fundamental.

Na obra, Isabel leva o leitor (ouvinte) a ser um receptáculo 10 Traduzido do fragmento em espanhol: "utiliza sus personajes para resaltar las figuras simbólicas más prominentes en los aspectos sociales y existenciales, destacan fundamentalmente la lucha entre la soledad y el deseo abierto de un querer renacer." 
de sua voz, cuja função é a de reavivar e manter viva para todo o sempre a chama sagrada da memória de sua família e de seu povo. Observe-se que, no discurso narrativo, as reminiscências são transmitidas como se fossem contadas oralmente por Isabel-pedra-cidade. Simbolicamente, ela assume aquelas atribuições tradicionalmente relegadas aos respeitáveis e sacralizados homens das comunidades em tempos mais remotos. Eis que o discurso de Isabel transcende e vai além dessas vozes masculinas de antigamente - uma vez que é voz e, ao mesmo tempo, está concretamente registrada nas páginas de um livro, como uma espécie de bíblia sagrada de seu povo.

Nesse viés, a personagem Isabel conta eternamente uma história - histórica. Suas evocações não se sujeitam à história oficial, mas às histórias sentidas, pressentidas e armazenadas em sua memória e na memória do povo - não somente integrando-o, mas também o representando. E assim o faz por sua própria volição, suas lembranças e interpretações.

A partir dessas reflexões, o leitor poderá reler e cotejar com outro olhar Los Recuerdos del Porvenir. Perceberá que sua mensagem não se extingue jamais, pois a pedra que aparece no suposto fechamento do livro, em lugar de indicar um denouement do relato, reconduz ao início da narrativa, a qual, ciclicamente, recomeça. Então, a mesma pedra 
que finalizaria a história, de fato a conta novamente, em consonância com a sua perspectiva e visão de mundo.

Neste processo repetitivo dos episódios narrados, obtém-se, paradoxalmente, a anulação do tempo que fica em suspenso. Ao eliminar a história "oficial" e privilegiar a memória histórica, Isabel busca se revivificar e consolidar. Reconquista o berço sagrado, onde o triunfo da eternidade sobre o tempo aponta a perfeição da gênesis em um tempo mítico.

Portanto, essa fenomenologia adotada por Elena Garro em nível textual prenuncia a germinação das sementes de renovadas Isabéis, que florecem sublimadas, na imorredoura batalha identitária do gênero feminino, ao encontro de seu verdadeiro Eu. Ao reassumir-se, pois, como Isabel-PedraComunidade, busca conquistar a sua liberdade, bem como a sua identidade individual, genérica e holística.

\section{REFERÊNCIAS}

Cavalcanti, Mercedes. (2011). Discurso de Posse da Academia Paraibana de Letras. João Pessoa: Editora Ideia.

Eliade, Mircea. (2001). El Mito del Eterno Retorno. Buenos Aires: Emecé, 2001.

Garro, Elena. (2010). Los recuerdos del Porvenir. México D.F.: Joaquín Mortiz.

Heidegger, Martin. (2009). Ser y Tiempo. Madrid: Editorial Trotta.

Lagarde, Marcela. (1990). Cautiverios de las mujeres: madresposas, monjas, putas, presas y locas. México: Universidad Nacional Autónoma de México. 
López González, Aralia. (Coord.). (1995). Sin imágenes falsas, sin falsos espejos: narradoras mexicanas del siglo XX. México DC: Colegio de México. Loya, Carlos. (2008). Matarazo y los espejos de Elena. In Patricia Rosas Lopátegui. Yo quiero que haya mundo... Elena Garro: 50 años de dramaturgía. Editorial Porrúa. México.

Nietzsche, F. W. (2011). Assim Falou Zaratustra. São Paulo: Companhia das Letras.

Maria Mercedes Ribeiro Pessoa Cavalcanti é escritora, romancista, contista, poeta, professora da UFPB e membro da Academia Paraibana de Letras, União Brasileira dos Escritores e Academia de Letras e Artes do Nordeste. 